\title{
PENGEMBANGAN MEDIA EVALUASI PENDIDIKAN "SI ASSEB" DI SMA NEGERI 1 MATANGKULI ACEH UTARA
}

\author{
Qusthalani \\ SMAN 1 Matangkuli Aceh Utara, Desa Blang Kecamatan Matangkuli \\ Korespondensi: qus.fs04@gmail.com
}

\begin{abstract}
Abstrak: Evaluasi pendidikan itu wajib dilaksanakan oleh guru sebagai penanggung jawab dalam proses pembelajaran siswa. evaluasi tersebut dapat dilakukan dengan jalan memberikan tes yang diadakan setiap selesai satu bab pembelajaran atau biasa disebut dengan ulangan harian, ujian tengah semester atau ujian akhir semester. Beberapa peneliti telah membuat software untuk mempermudah guru dalam menganalisis hasil jawaban siswa, Namun, software yang dibuat tersebut hanya menyajikan hasil belajar siswa dalam bentuk benar dan salah saja. Soal-soal yang telah dibuat tersebut tidak dapat melihat sejauhmana siswa tersebut tersebut sudah memahami suatu materi dari soal yang diuji, sehingga software yang akan penulis buat soal pilihan ganda dua tingkat. Soal tersebut tidak hanya melihat benar dan salah dari jawaban siswa, tetapi dapat juga menganalisis tingkat pemahaman siswa dari suatu konsep dalam soal yang diuji tersebut. Sistem asesmen ini akan berbasis web sehingga nama sistem yang dikembangkan adalah Si Asseb (Aplikasi Assesment Berbasis WEB).
\end{abstract}

Kata Kunci: Evaluasi, tes, WEB, Si Asseb

\section{DEVELOPMENT OF "SI ASSEB" EDUCATION EVALUATION MEDIA IN HIGH SCHOOL MATANGKULI NORTH ACEH}

\begin{abstract}
Educational evaluation must be carried out by the teacher as the person in charge of the student learning process. the evaluation can be done by giving a test that is held every time a chapter of learning is completed or commonly called a daily test, midterm or final semester examination. Some researchers have made software to facilitate teachers in analyzing the results of student answers, however, the software created only presents the results of student learning in the right and wrong forms only. The questions that have been made cannot see how far the student has understood a material from the question being tested, so the software that the writer will make is a two-level multiple choice. These questions not only see the true and false answers of students, but can also analyze the level of students' understanding of a concept in the question being tested. This assessment system will be web-based so the name of the system developed is Si Asseb (WEB-Based Assessment Application).
\end{abstract}

Key words: Evaluation, tests, WEB, Di Asseb 
Salah satu tugas guru untuk menghasilkan lulusan yang berkualitas ialah menentukan kegiatan pembelajaran yang cocok pada saat proses belajar berlangsung. Kegiatan pembelajaran tersebut adalah penentuan model, strategi, pendekatan, metode, teknik pembelajaran maupun media pembelajaran. Pemilihan model atau media pembelajaran yang tepat dalam setiap kegiatan pembelajaran untuk mempermudah siswa memahami materi yang disajikan guru sehingga hasil belajar siswa lebih baik.

Menurut Sanjaya (2006) Belajar bukanlah menghafal sebuah fakta atau informasi. Belajar adalah berbuat; memperoleh pengalaman tertentu sesuai dengan tujuan yang di harapkan. Karena itu, strategi pembelajaran harus dapat mendorong aktivitas siswa. Aktivitas tidak dimaksudkan terbatas pada aktivitas fisik, akan tetapi juga meliputi aktivitas yang bersifat psikis seperti aktivitas mental.

Belajar fisika bukanlah belajar menghayal dengan berceramah di depan kelas, karena pelajaran Fisika memiliki tujuan yang komplek didalam sebuah kurikulum yaitu seperti diugkapkan Suparman (2007), "Tujuan dari pelajaran IPA yaitu memberikan pengetahuan dan keterampilan kepada siswa untuk menguasai dasar-dasar sains dalam rangka penguasaan IPTEK". Pembelajaran Fisika meliputi empat unsur yaitu sikap, proses, produk dan aplikasi. Sikap terdiri dari rasa ingin tahu tentang benda, fenomena alam, makhluk hidup, serta hubungan sebab akibat yang menimbulkan masalah baru. Proses terdiri dari pemecahan masalah melalui metode ilmiah, produk berupa fakta, prinsip, teori, dan hukum. Aplikasi yaitu penerapan metode ilmiah dan konsep IPA dalam kehidupan sehari-hari (Balitbang Nasional, 2006).

Untuk melihat sejauhmana pendidik sudah berhasil dalam suatu pembelajaran, maka diperlukan tes atau evaluasi terhadap hasil belajar. Evaluasi pendidikan adalah kegiatan pengendalian, penjaminan, dan penetapan mutu pendidikan terhadap berbagai komponen pendidikan pada setiap jalur, jenjang, dan jenis pendidikan sebagaibentuk pertanggungjawaban penyelenggaraan pendidikan." (PP No.19 Tahun 2005). Menurut peraturan tersebut, proses evaluasi pendidikan itu wajib dilaksanakan oleh guru sebagai penanggung jawab dalam proses pembelajaran siswa. Dalam rangkaian proses evaluasi pendidikan tersebut, guru harus melakukan evaluasi pembelajaran yang merupakan bagian dari rangkaian proses evaluasi pendidikan. Proses evaluasi tersebut dapat dilakukan dengan jalan memberikan tes atau ujian yang bisa diadakan setiap selesai satu bab pembelajaran atau biasa disebut dengan ulangan harian, ujian tengah semester atau ujian akhir semester. Tes yang diberikan dapat berupa soal-soal pilihan ganda, isilah dan atau essay.

Suharsono (2014) menyebutkan evaluasi pendidikan memiliki peranan yang sangat penting, terutama untuk melihat keberhasilan guru dalam melahirkan Sumber Daya Manusia yang berkualitas. Seorang guru diharuskan mampu memillih evaluasi pembelajaran yang sesuai dengan program kegiatan pembelajaran, dengan pengembangan evaluasi pembelajaran yang tepat dan sesuai, maka dapat meningkatkan prestasi belajar siswa serta berpengaruh positif terhadap keefektifan belajar.

Namun, dalam pelaksanaannya seringkali guru memberikan tes kepada siswa hanya untuk mengukur kemampuan siswa dan hanya menghitung jawaban benar atau salahnya saja yang nantinya akan jadi tolak ukur nilai kemampuan siswa tersebut. Padahal, seharusnya tes tidak hanya untuk mengukur kemampuan siswa tetapi juga harus menjadi bahan evaluasi bagi guru tentang pemahaman siswa akan pembelajaran yang telah dilaksanakan.

Hal tersebut sulit dilakukan karena dalam prosesnya soal-soal tes yang diberikan tidak dirancang untuk mendeteksi tingkat pemahaman siswa dalam pembelajaran. Hal 
ini dapat diatasi bila menggunakan sebuah alat evaluasi berupa sistem penilaian atau sistem asesmen yang dirancang untuk mengukur tingkat kemampuan siswa, dan juga dirancang untuk mendeteksi tingkat pemahaman siswa terhadap poin-poin yang diujikan.

Perkembangan zaman yang semakin cepat terutama dalam bidang teknologi pada saat ini memungkinkan pendidik mengembangkan sistem asesmen yang berkualitas, bukan hanya mendetekasi kemampuan siswa tetapi juga tingkat pemahaman siswa tersebut. Sistem asesmen yang dikembangkan didalamnya akan menggunakan instrumen tes berupa soal pilihan ganda dua tingkat. Sistem ini dirancang untuk merekam setiap siswa dalam memilih opsi jawaban baik benar ataupun salah. Setiap siswa harus memilih pilihan jawaban dan memberikan alasan pada pilihan yang ada. Selanjutnya setiap jawaban-jawaban siswa yang telah masuk ke dalam sistem akan dijadikan sebuah pelaporan bagi guru tentang tingkat pemahaman siswa terhadap suatu soal (Hakim, 2012).

Sistem asesmen ini akan berbasis web sehingga nama sistem yang dikembangkan adalah Si Asseb (Aplikasi Assesmen Berbasis WEB). Keuntungan yang akan diperoleh dari sistem berbasis web adalah bersifat multi platform sehingga dapat digunakan oleh sistem operasi apapun, karena apabila sistem tersebut hanya dapat digunakan di salah satu sistem operasi saja apalagi berbayar maka akan sulit untuk dilirik para pengguna. Selain itu, selama tersedia koneksi jaringan atau internet, maka guru dan siswa bisa melaksanakan proses evaluasi pembelajaran dengan menggunakan sistem ini.

Keuntungan lain yang dapat diperoleh dari $\mathrm{Si}$ Asseb adalah pengguna dapat membuat skala tersendiri dan memungkinkan pengguna untuk langsung menggunakan data masalah dalam sebuah tabel multikriteria sehingga perhitungannya cepat dan sederhana. Si Asseb juga bisa digabungkan dengan beberapa mata pelajaran lainnya di sekolah, sehingga menjadi sebuah media evaluasi yang komplek di sekolah dalam mendukung evaluasi berbasis WEB.

Tujuan dari penelitian ini adalah untuk mengidentifikasi peningkatan hasil belajar siswa pada materi Fluida Dinamis melalui penerapan media evaluasi "Si Asseb" di SMAN 1 Matangkuli.

\section{METODE}

Metode penelitian yang digunakan adalah R \& D model 4D. Keempat tahap pengembangan instrumen ini adalah : (1) Tahap Pengembangan butir soal; (2) Tahap perancangan sistem; (3) Tahap uji kelayakan soal dan sistem oleh ahli dan calon guru.; (4) Tahap penerapan produk akhir. Pengembangan yang dilakukan adalah pada media ujian onlinenya.

Sebelum media dan soal diujicobakan pada siswa, maka media tersebut di validasi oleh pakar media yaitu Dr. Nasrullah Idris, M.Si dan ahli evaluasi yaitu Prof. Yusrizal, M.Pd. Media dan soal telah dilakukan revisi sebanyak dua kali, baru di uji cobakan pada siswa SMAN 1 Matangkuli Aceh Utara.

\section{HASIL PENELITIAN}

Berdasarkan penelitian mengenai pengembangan aplikasi fisika berbasis pendekatan saintifik pada materi fluida dinamis yang telah dilakukan, diperoleh hasil penelitian serta pembahasannya pada masing-masing tahap pengembangan butir soal, 
Tahap Perancangan Sistem, Tahap Uji Kelayakan Media, dan Penerapan Produk Akhir adalah sebagai berikut.

\section{Tahap Pengembangan Butir Soal}

Tahap analisis merupakan langkah paling awal dalam melakukan pengembangan butir soal yang dilakukan dalam penelitian ini. Tahap analisis dalam penelitian ini meliputi analisis kurikulum dan analisis karakteristik siswa.

Berdasarkan beberapa karakteristik siswa tersebut maka peneliti mengembangkan aplikasi SI ASSEB. Selain untuk memberikan motivasi, aplikasi dapat efektifi dan efisien bagi guru dalam setiap ujian, sehingga diharapkan siswa akan lebih aktif dalam pembelajaran. Materi yang dipilih untuk dikembangkan dalam aplikasi adalah materi fluida dinamis.

\section{Tahap Perancangan} berikut:

Hasil dari tahap perancangan yang telah dilakukan oleh peneliti adalah sebagai

\section{a. Penyusunan Draft Aplikasi}

a) Halaman Depan

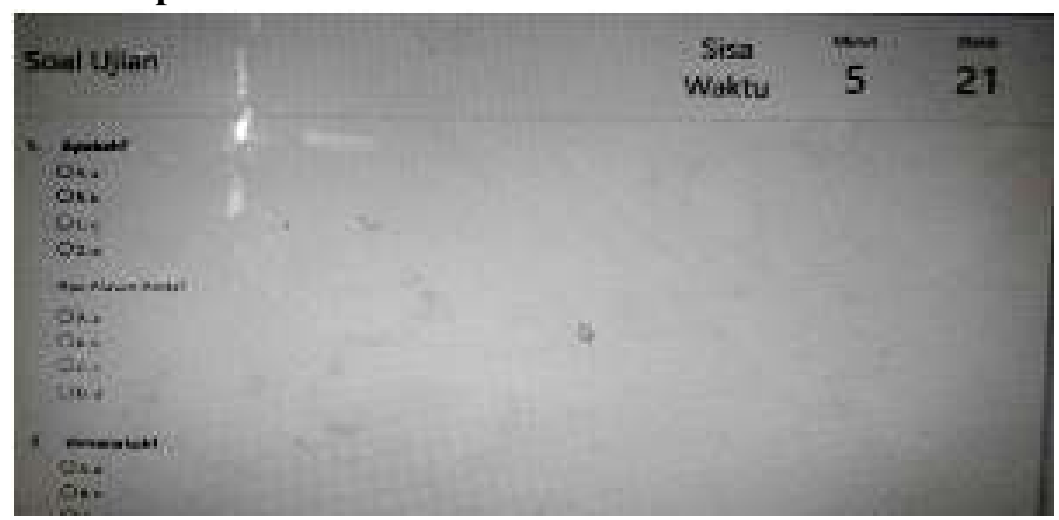

Gambar 1 Tampak Halaman Depan

b) Halaman Guru

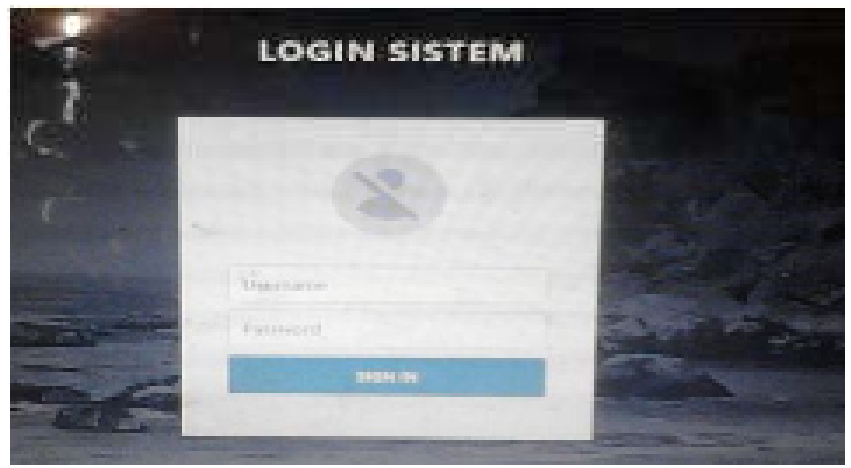




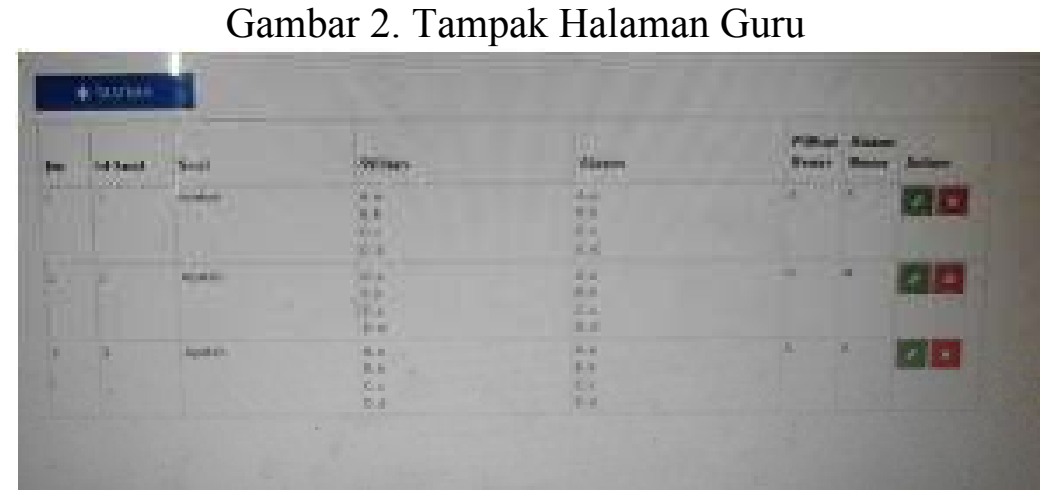

Gambar 3. Tampak Halaman Tambah Soal

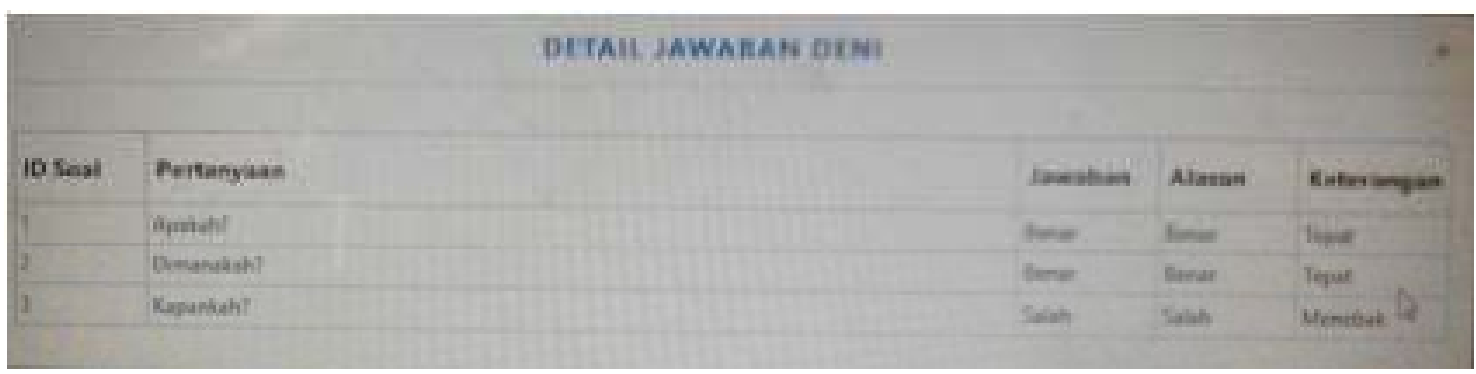

Gambar 4. Tampak Halaman Rekapitulasi Nilai

\section{b. Penyususan Instrumen Penilaian, Angket Tanggapan Guru dan Siswa}

Terdapat tiga hal yang akan dikembangkan dalam tahap ini, yaitu Instrumen Penilaian, Angket Tanggapan Guru, dan Siswa. Pengembangannya adalah sebagai berikut:

1) Instrumen Penilaian

2) Angket Tanggapan Guru

3) Angket Tanggapan Siswa

\section{Tahap Uji Kelayakan Produk (Validasi)}

Deskripsi pada tahap validasi adalah sebagai berikut:

1) Validasi Instrumen Penilaian, Angket Tanggapan Guru, dan Siswa

Validasi Instrumen Penilaian dan Angket Tanggapan Siswa dilakukan oleh seorang dosen ahli, yaitu Prof. Dr. Yusrizal, M.Pd

2) Validasi Produk

Produk yang dikembangkan ini divalidasi oleh 2 orang ahli yang terdiri dari 1 orang dosen ahli media dan 1 orang guru fisika SMA Negeri 1 Matangkuli. Adapun 1 orang dosen ahli media yaitu Dr. Nasrullah Idris, M.Si, sedangkan 1 orang guru SMA N 1 Matangkuli adalah ibu Cut Nurdiana, S.Pd Hasil dari validasi produk adalah sebagai berikut:

3) Analisis Data Validasi

a. Analisi Data Validasi Ahli Media 
Dari hasil penilaian oleh Dosen Ahli Media, yaitu Bapak Dr. Nasrullah Idris,M.Si diperoleh skor rata-rata total 3,3 dengan kriteria kualitatif baik. Aspek data Ahli Media dinyatakan pada tabel berikut:

Tabel 1 Hasil Analisis data Ahli Media

\begin{tabular}{|l|l|c|c|}
\hline No & \multicolumn{1}{|c|}{ Aspek } & Rata-rata & Kriteria Kualitatif \\
\hline 1 & Ukuran Aplikasi & 3,0 & Baik \\
\hline 2 & Desain halaman depan & 3,6 & Sangat Baik \\
\hline 3 & Isi Aplikasi & 3,4 & Baik \\
\hline \multicolumn{2}{|l|}{} & 3,3 & Baik \\
\hline
\end{tabular}

Kriteria kelayakan bahan ajar diperoleh dengan cara mengkonversikan data kualitatif berupa skor tiap aspek kelayakanmaupun skor total ke dalam tabel konversi kelayakan, sehingga diperoleh hasil kualitatif pada tabel tersebut. Perhitungan pada tabel kelayakan dapat dilihat pada lampiran.

\section{b. Analisis Data Validasi Ahli Evaluasi}

Hasil data validasi dosen ahli evaluasi, yaitu Prof. Dr. Yusrizal, M.Pd memperoleh skor rata-rata total 3,6 dengan kriteria kualitatif sangat baik. Aspek butir-butir penilaian ahli materi dinyatakan pada tabel berikut:

Tabel 2 Hasil Analisis Data Ahli Materi

\begin{tabular}{|l|l|c|c|}
\hline No & \multicolumn{1}{|c|}{ Aspek Penilaian } & Rata-rata & $\begin{array}{c}\text { Kriteria } \\
\text { Kualitatif }\end{array}$ \\
\hline 1 & Kelayakan Isi & 3,5 & Sangat Baik \\
\hline 2 & Kelayakan Penyajian & 3,8 & Sangat Baik \\
\hline 3 & Saintifik & 3,5 & Sangat Baik \\
\hline & Rata-rata & 3,6 & Sangat Baik \\
\hline
\end{tabular}

Kriteria kevalidan aplikasi diperoleh dengan cara mengkonversikan total skor tiap aspek dalam tabel konversi kelayakan.

\section{c. Analisis Data Lembar Penilaian Guru Fisika}

Draft aplikasi yang telah dikembangkan, juga divalidasikan kepada guru fisika di sekolah. Guru yang menjadi validator aplikasi yang telah dikembangkan adalah ibu Cut Mardiana, S.Pd. Hasilnya dapat dalam tabel di bawah ini.

Tabel 3 Analisis data Lembar Penilaian Guru Fisika

\begin{tabular}{|l|l|c|c|}
\hline No & \multicolumn{1}{|c|}{ Aspek } & Rata-rata & Kriteria Kualitatif \\
\hline 1 & Tampilan & 3,7 & Sangat Baik \\
\hline 2 & Penyampaian Materi & 3,4 & Baik \\
\hline 4 & Kebermanfaatan & 3,4 & Baik \\
\hline
\end{tabular}


Kriteria kelayakan bahan ajar diperoleh dengan cara mengkonversikan data kualitatif berupa skor tiap aspek kelayakanmaupun skor total ke dalam tabel konversi kelayakan, sehingga diperoleh hasil kualitatif pada tabel tersebut. Perhitungan pada tabel kelayakan dapat dilihat pada lampiran.

\section{Tahap Penerapan Produk Akhir}

\section{a. Uji Coba aplikasi}

Pada pembelajaran menggunakan aplikasi, terlihat bahwa siswa tertarik dan termotivasi untuk dapat menyelesaikan masalah yang ada pada aplikasi. Hal ini dapat dilihat ketika siswa mengalami kesulitan dalam menyelesaikan kegiatan pada aplikasi, siswa akan bertanya kepada guru mengenai solusi atau cara yang harus mereka tempuh untuk dapat menyelesaikan kesulitan yang sedang mereka hadapi.
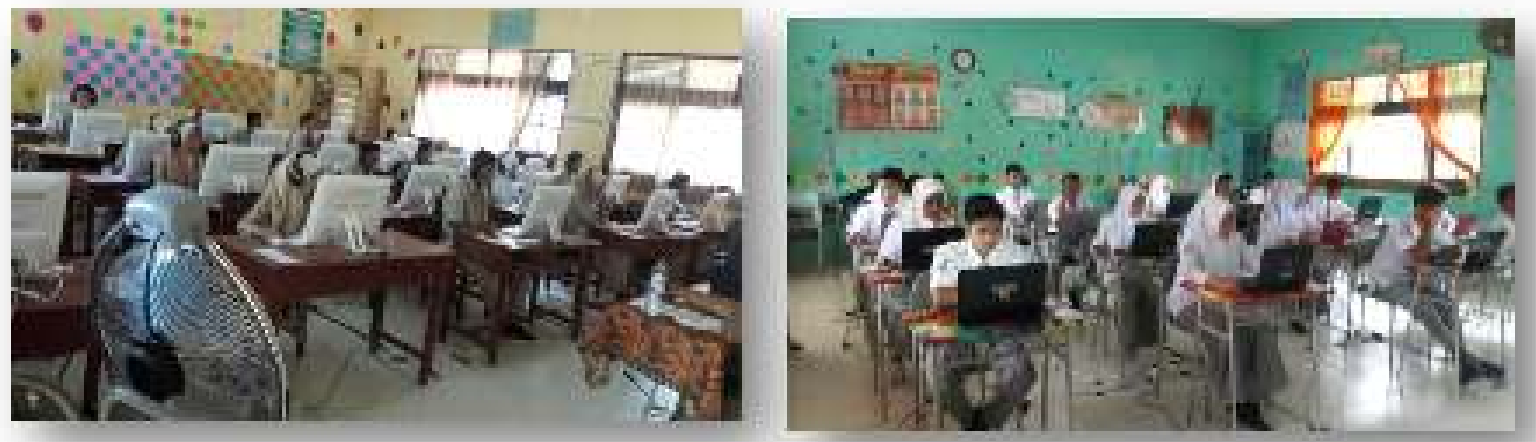

Gambar 6. Implementasi Si Asseb di SMAN 1 Matangkuli

\section{a. Analisis Data Kepraktisan Aplikasi}

Rata-rata seluruh aspek butir penilaian adalah 3,4 yang berada pada kriteria kualitatif baik. Dengan rincian sebagai berikut:

Tabel 4 Hasil Analisis Angket Respon Siswa

\begin{tabular}{|c|l|c|c|}
\hline No & \multicolumn{1}{|c|}{ Aspek } & Rata-rata & Kriteria Kualitatif \\
\hline 1 & Kesesuaian Bahasa & 3,0 & Baik \\
\hline 2 & Tampilan Penyajian & 3,8 & Sangat Baik \\
\hline 3 & Kemudahan & 3,5 & Sangat Baik \\
\hline & Rata-rata & 3,4 & Baik \\
\hline
\end{tabular}

Jadi, dapat disimpulkan bahwa bahan ajar yang dikembangkan memiliki tingkat kepraktisan dengan kriteria baik. Hasil analisis respon siswa selengkapnya dapat dilihat pada lampiran. Dari hasil angket respon siswa, juga diperoleh komentar dan saran sebagai berikut:

1. Ada siswa yang berpendapat agar aplikasi dibuat lebih jelas lagi.

2. Aplikasi ini mampu menghadirkan suasana yang berbeda saat mengikuti ujian.

3. Penyampaian soal pada aplikasi menarik, mudah dipahami. 


\section{b. Analisis Data Keefektifan Aplikasi Melalui Peningkatan Hasil Belajar}

Keefektifan aplikasi diukur menggunakan analisis pre test pada awal pembelajaran sebelum menggunakan aplikasi dapat dilihat dalam grafik berikut ini.

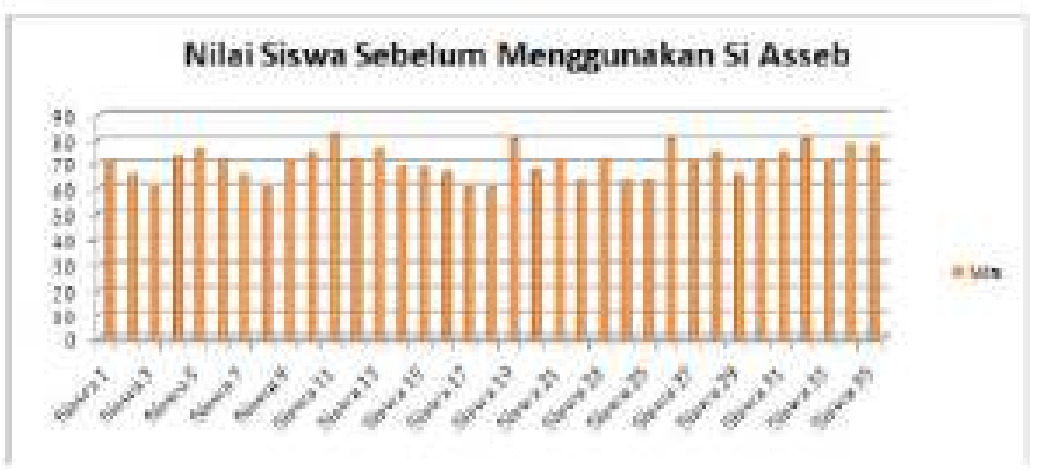

Grafik 1. Nilai Siswa Sebelum Menggunakan Si Asseb

Setelah pre tes maka peneliti melakukan postes untuk melihat sejauhmana keefektifan penggunaan aplikasi yang telah dikembangkan didalam pembelajaran dapat dilihat dalam grafik berikut ini.

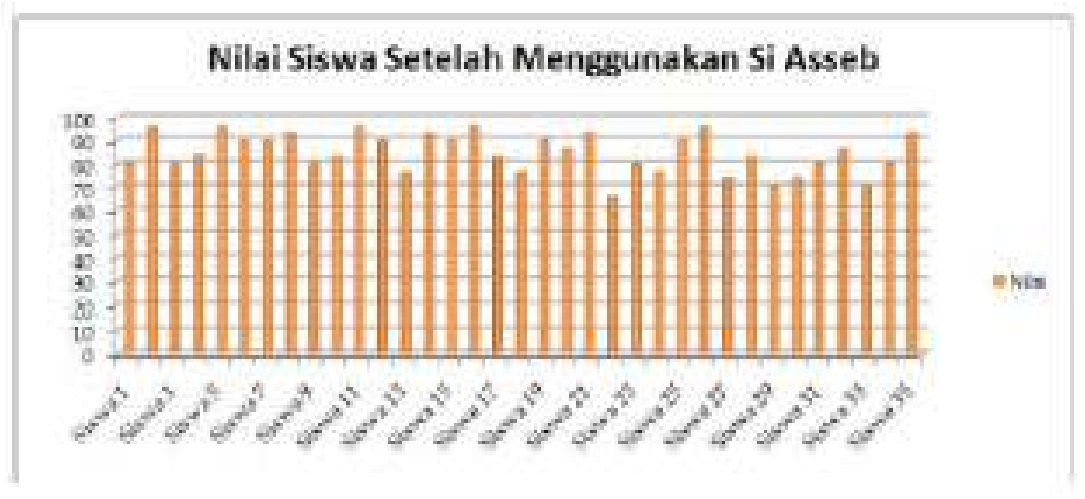

Grafik 2. Nilai Siswa Setelah Menggunakan Si Asseb

Jadi, dapat disimpulkan bahwa; (1) Aplikasi yang dikembangkan telah sesuai dengan langkah penyusunan dan pengembangan aplikasi dengan model 4 D TUYSUZ, yaitu analisis (analysis), desain (design), pengembangan (development), implementasi (implementation), dan evaluasi (evaluation), (2) Aplikasi yang dikembangkan telah sesuai dengan tahapan pendekatan saintifik yaitu understand the problem(memahami masalah), develop a plan (membuat rencana penyelesaian masalah), carry out the plan (melaksanakan rencana yang telah ditetapkan), dan look back (memeriksa ulang jawaban yang diperoleh). (3) Aplikasiyang dikembangkan telah memenuhi kriteria kevalidan, kepraktisan, dan keefektifan. 


\section{PENUTUP}

Aplikasi ujian online SI ASSEB pada materi fluida dinamis telah berhasil diselesaikan, maka dapat disimpulkan: (a) Aplikasi Assesment Berbasis Web ini di rancang melalui proses 4D yaitu pengembangan butir soal, perancangan sistem, pengujian kelayakan dan penerapan produk akhir. Hasil dari validasi modul yang dikembangkan diperoleh persentase $92,3 \%$ dari ahli materi, yang berarti tingkat kelayakan sangat tinggi, dari ahli media diperoleh persentase $86,7 \%$, yang berarti tingkat kelayakan sangat tinggi,dari uji coba produk diperoleh persentase $94,5 \%$, yang berarti tingkat kelayakan sangat tinggi,dan dari uji coba pemakaian mendapat persentase $81,2 \%$, yang berarti tingkat kelayakan sangat inggi. Sehingga diperoleh persentase rata-rata sebesar 88,675\% dengan tingkat kelayakan sangat tinggi. (b) Aplikasi Assesment Berbasis Web juga dapat meningkatkan haisl belahar siswa, hal dapat dilihat dari nilai sikap sebesar $100 \%$ kegiatan belajar mencapai ketuntasan belajar secara kelompok (klasikal). Dengan demikian, aplikasi SI ASSEBdapat dinyatakan layak.

\section{DAFTAR PUSTAKA}

Balitbang Kemdikbud. 2006. Standar Operasional Proses Kurikulum KTSP. Jakarta: Kemdikbud.

Hakim, A, Liliasari, Kadorohman, A. 2012. Student Concept Understanding of Natural Products Chemistry in Primary and Secondary Metabolites Using the Data Collecting Technique of Modified CRI. International Online Journal of Educational Sciences. 4(3): 544-553.

Sanjaya, Wina. 2006. Strategi Pembelajaran Berorientasi Proses. Jakarta: Kencana.

Suharsono. 2014. Evaluasi Pendidikan. Jakarta: Bumi Aksara.

Suparman. 2007. Pendidikan IPA Sekolah Menengah. Jakarta: Studi Magister Pendidikan Matematika dan IPA UPI. 